\title{
Religion, communism, and Ratu Adil \\ Colonialism and propaganda literature in 1920s Yogyakarta
}

\author{
SRI MARGANA
}

\begin{abstract}
This article examines the social realities of literary works and the colonial perceptions of socio-political movement inspired by the ideologies of Islam, communism, and the Just King (Ratu Adil). The main sources for this study are four propaganda literatures published by the Resident of Yogyakarta, Louis Frederik Dingemans (1924-1927). It employs post-colonial literary theory to analyse the colonial authority's perceptions of Islam, communism, and Ratu Adil, and examines how colonial rulers (as colonizers) positioned themselves as above indigenous society (the colonized) as the guardians of moral, social, and political order.
\end{abstract}

KEYWORDS

Colonialism; literature; propaganda; communism Ratu Adil; religion; Yogyakarta.

\section{Colonialism AND the PEASANT MOVEMENTS OF JAVA}

By the end of Java War in 1830 the Dutch colonial implemented the Cultivation System (Cultuurstelsel) in Java. This gave rise to the development of the plantation of export crops in Java such as tobacco, sugarcane, indigo, and coffee. In the autonomous principalities of Java the plantations ran by private entrepreneurs. The rise of the colonial plantations in Java in the nineteenth century resulted in various social and economic issues. The region experienced agrarian involution, but at the same time available agricultural land was reduced. Sustained population growth exacerbated this situation, leaving farmers with little recourse but shared poverty. ${ }^{1}$

1 Regarding the concept of shared poverty, see Jennifer Alexander and Paul Alexander 1982.

SRI MARGANA is a lecturer and currently Head of the Department of History at the Faculty of Cultural Sciences, Gadjah Mada University, Yogyakarta. He received his PhD from Leiden University in 2007 with a dissertation Java's last frontier; The struggle for the hegemony of Blambangan, c. 1763-1813. His research focuses on cultural and intellectual history in pre-colonial and colonial Indonesia. Sri Margana may be contacted at: s.margana@gmail.com. 
Such socio-economic pressures laid fertile ground for social movements founded in Islamic ideologies like the concept of Ratu Adil (Just King), and millenarianism, which sought the return of Java's former glory and improved socio-economic conditions. Such movements dealt directly with the colonial forces, who saw them as threats to security and order. These movements are carefully recorded in colonial archives from the nineteenth century and early twentieth century. ${ }^{2}$

The peasant movements of Java have been widely studied by Indonesian historians. According to Sartono Kartodirdjo, the Javanese peasant movements of the nineteenth and early twentieth century were archaic in nature, with simple organizational structures, programs, tactics, and strategies; compared to modern social movements such as fascism, communism, and socialism, they remained embryonic. Another reason for these movements being identified as archaic is their lack of clear goals and orientations, as they were not certain what sort of social structure they wanted. The religio-magic character of these movements also contributed to this appellation. Sartono Kartodirdjo identified six categories of such social movements: social banditry, protest movements (against unjust laws), revivalist movements, nativist movements, messianic movements, and jihad movements. However, all of these categories were identified by the colonial government as criminal through terms such as rustverstoring (disturbing the peace), woelingen (unrest), and onlusten (riots) (Kartodirdjo 1981: 7-9).

The socio-economic pressures of the times had dual responses. Most extreme was the establishment of social movements that used violence to reach their goals; more moderate were social deviances and crime, known as volksondeugden (social disorder) under colonial law or Ma Lima (Main, Minum, Madat, Maling, dan Madon; Gambling, Drinking, Opium Use, Theft, and Whoring) in Java. The island was also afflicted by social disorder as residents sought a means to free themselves from the socio-economic pressures of colonialism. These deviant behaviours were seen by the colonial government as having a detrimental effect on social order, one no less severe than that of social movements. Social deviance was seen as endemic to the era, with broader participation than social movements, affecting not only the common people or village elites but also the priyayi (court or state bureaucrat) and bangsawan (nobility) in urban areas.

\section{SOCIO-POLITICAL DEVELOPMENTS IN YOGYAKARTA IN THE EARLY TWENTIETH CENTURY}

The early twentieth century marked the beginning of a new socio-political era in the Netherlands East Indies, particularly following the introduction of an Ethical Policy (Ethische Politiek) in the first decade of the twentieth century that offered the Indonesian people more access to Western-style education. Three new phenomena occurred in subsequent years. First, a new class of

2 See the series of colonial archives published by the National Archive of Indonesia (Kartodirdjo 1981). 
educated elites emerged from the indigenous population, as studied by Dutch historian, Robert van Niel (Van Niel 1960). Second, a new class of priyayi was created out of the colonial bureaucrats, as comprehensively studied by another Dutch historian Heather Sutherland (Sutherland 1976). Third, new nationalist organizations were established by the two new classes of elite mentioned above, as examined in depth by Japanese historian, Takashi Shiraisi (Shiraisi 1990). This last phenomenon significantly influenced the socio-political development of the Indonesian archipelago.

These three phenomena were also present in early twentieth century Yogyakarta. In this period, three socio-political organizations were most prominent: Muhammadiyah, Budi Utomo, and the Communist Party of Indonesia (Partai Komunis Indonesia, PKI). According to Alfian (1989) and Mitsuo Nakamura (2012), who studied the movement, Muhammadiyah has been one of the most influential Muslim movements in Indonesia, eclipsed only by the Sarekat Islam (Islamic Union) and the Nahdlatul Ulama. ${ }^{3}$ Smaller modernist Muslim movements were no less important, however. As shown by Deliar Noer, such movements endured even after Indonesia's independence (Noer 1973). They focused on religious activities, the modernization of Islam, and education. These movements were also political, addressing at first not on the colonial government but opposing the rise of communism. Communism, similarly, was highly influential in Yogyakarta, and PKI's first congress (1924) was held in Kota Gede - known as the heart of Islamic and Muhammadiyah activities in Yogyakarta. During the Congress, the situation almost escalated to physical violence as PKI members made speeches and formed cavalcades. The Muhammadiyah community opposing the idea of the committee of the congress that willing to undergo mass parade throughout the main street of Yogyakarta. Conversely, the Ratu Adil ideology was not new to the twentieth century. It had been created during the Java War (1825-1830), by Prince Dipanegara, who sought the downfall of the colonial government. ${ }^{4}$ Even after Dipanegara was captured and exiled to Sulawesi, political movements with the Ratu Adil ideology endured.

Aside from Islamic and communist social movements, various Protestant and Catholic missionary movements were active and growing in Yogyakarta. They not only spread Christianity, but established schools, hospitals, and various charitable foundations. Louis Frederik Dingemans (see Picture 1), who took office as Resident of Yogyakarta in 1924, had close ties with these missionaries, and was even able to involve Sultan Hamengku Buwana VIII in the Yogyakarta Christians' various social activities.

Several photographs (see Pictures 2-6) show the close relationship between the two men, who appeared together on various occasions, including at parties, sugar factories inspection, and the inauguration of projects such as the Petronella Christian Foundation's hospital, roads, bridges, and dams.

3 Usually abbreviated as NU, a traditionalist Suni Islam organization established in 1926 as a response to the rise of Wahhabism and Islamic modernism.

4 Regarding Dipanegara as Ratu Adil, see Peter Carey 2011. 
However, the relationship between the two was frequently tense, as Dingemans was seen as frequently promoting the interests of the missionaries over those of the Muslim majority. This is noted, for example, in a protest letter sent by Fachrudin, junior secretary of Muhammadiyah and Sarekat Islam member, to Sultan Hamengku Buwana VIII in 1925. At the time, the Sultan (under the influence of Dingemans) had reduced subsidies for Muhammadiyah-run orphanages while increasing money for the Sultanate Orphanage, which had been entrusted to the Petronella Christian Foundation (Steenbrink 1993: 136).

When Christmas Day coincided with Garebeg Maulud (Maulid, the anniversary of the Prophet Muhammad's birth), Dingemans asked the Sultan to postpone Garebeg celebrations, thereby giving the Christian population the opportunity to celebrate Christmas first. On another occasion, Dingemans unilaterally reduced the subsidies given to the Palace family and staff, using the money for missionary activities. This ultimately drew protest from Sultan Hamengku Buwana VIII, who sent a letter to Governor-General Dirk Fock in Batavia, urging the colonial government to do something about Dingemans, whom he perceived as creating political unrest. The Governor-General was unwilling to allow such political problems to trigger insurgency; the colonial government had already been busy with such social and political movements for the first two decades of the twentieth century. Finally, the GovernorGeneral decided to remove Dingemans from his office, citing intolerance, while promising him a spot on the Council of the Indies. This promise was not kept, as Fock returned Dingemans to the Netherlands (see Nakamura 1983; Alfian 1989: 340-341; Steenbrink 2007: 405).

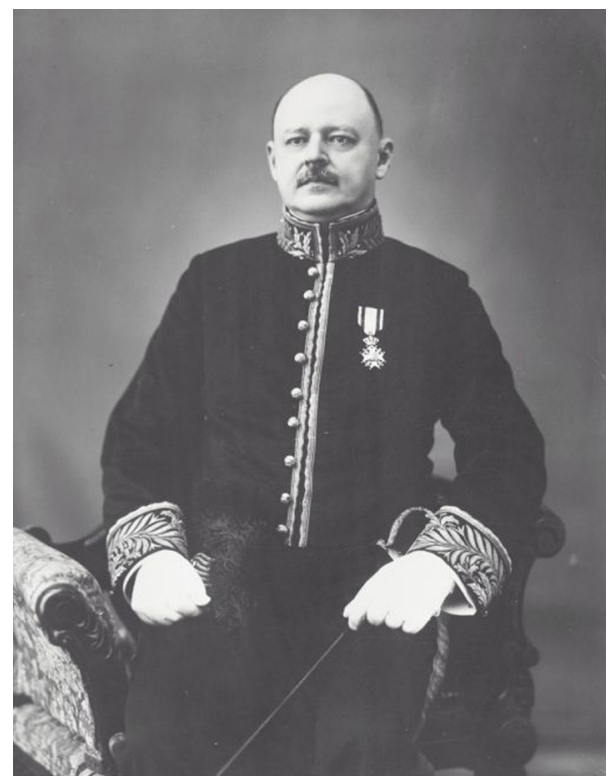

Picture 1. Resident of Yogyakarta, Louis Frederik Dingemans. (The photograph in the collection of the Tropenmuseum: TM-60041526). 

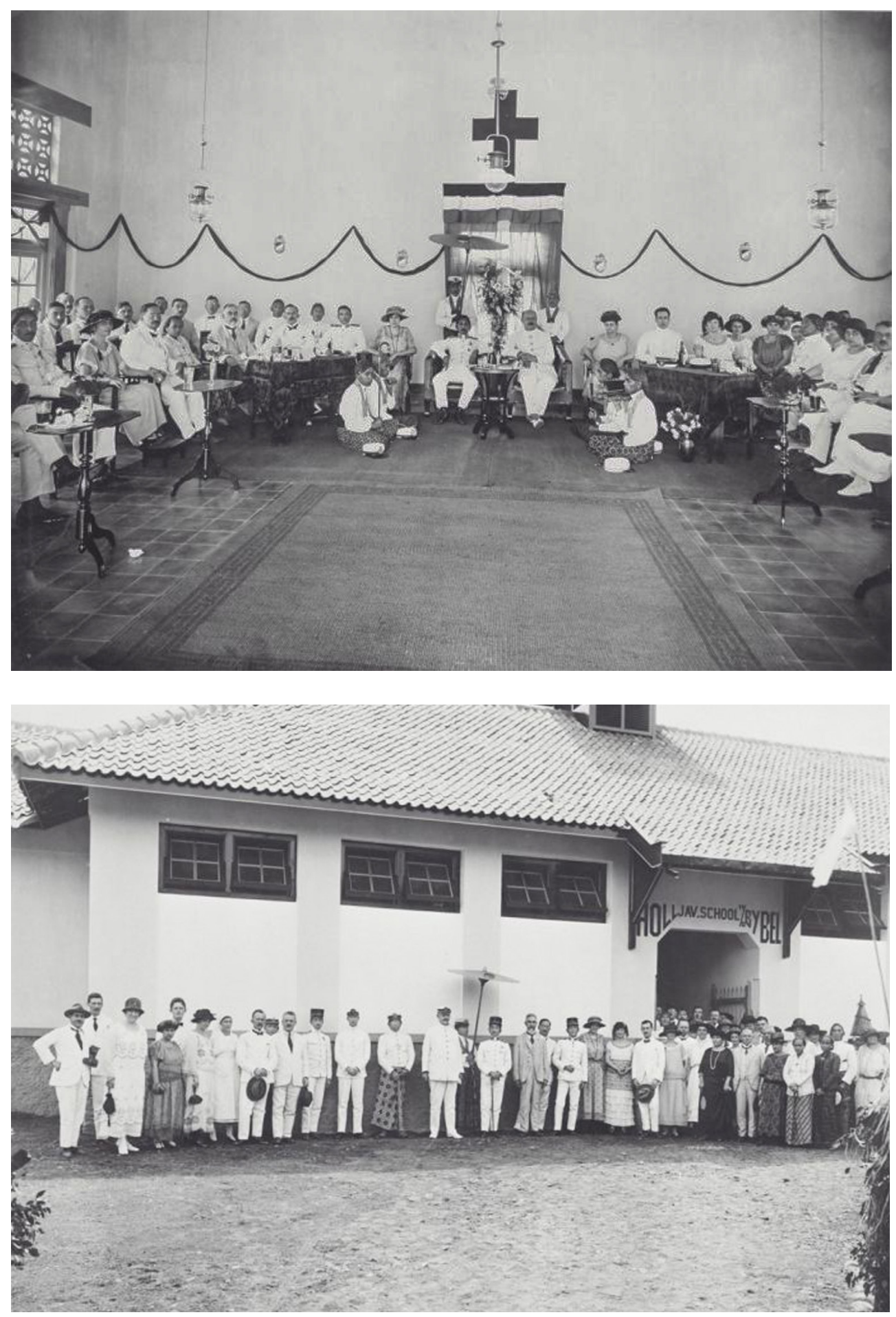

Pictures 2 and 3. Resident L.F. Dingemans and Sultan Hamengku Buwana VIII visiting the Hollandse-Javaanse School met de Bijbel (Dutch-Javanese Bible School). (Photographs 2 and 3 in the collection of the Tropenmuseum: TM-60041536 and TM-60041535). 


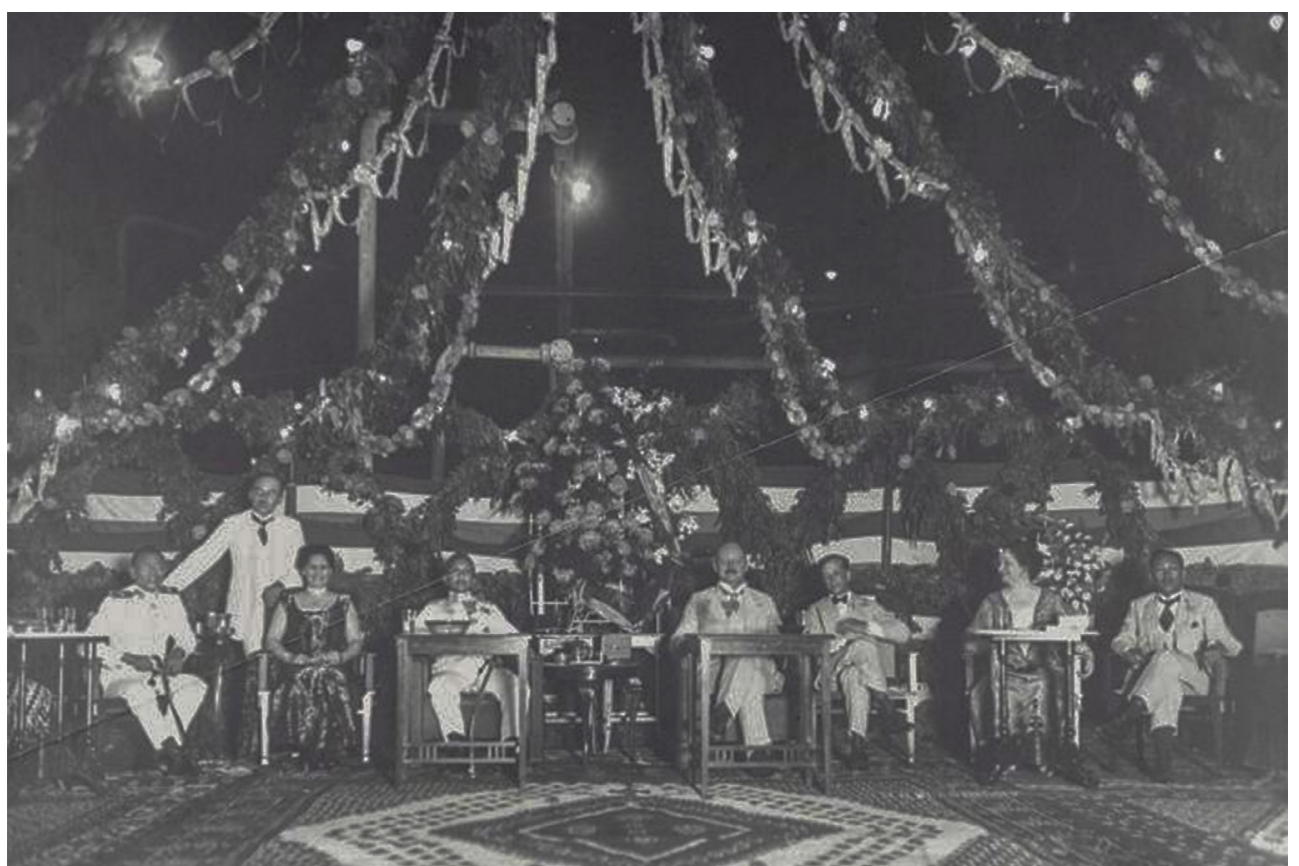

Picture 4. Resident L.F. Dingemans with Sultan Hamengku Buwana VIII during a ceremony commemorating the 60th anniversary of the Gesikan Sugar Factory. (Photograph in the collection of the Tropenmuseum: TM-60041546).

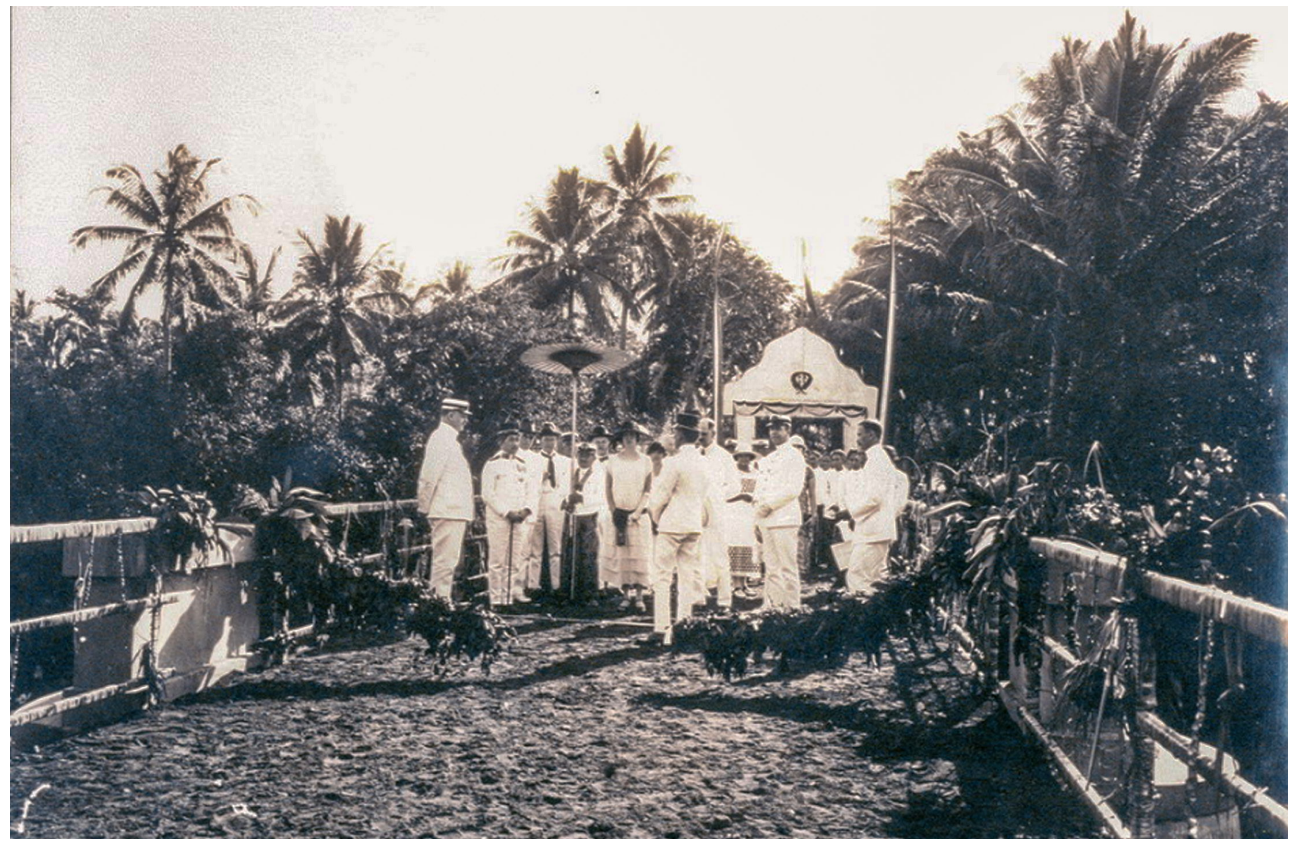

Picture 5. Resident L.F. Dingemans with Sultan Hamengku Buwana VIII during a visit to the Prins Juliana School. (Photograph in the collection of the Widya Pustaka Pakualaman Yogyakarta, Album F). 


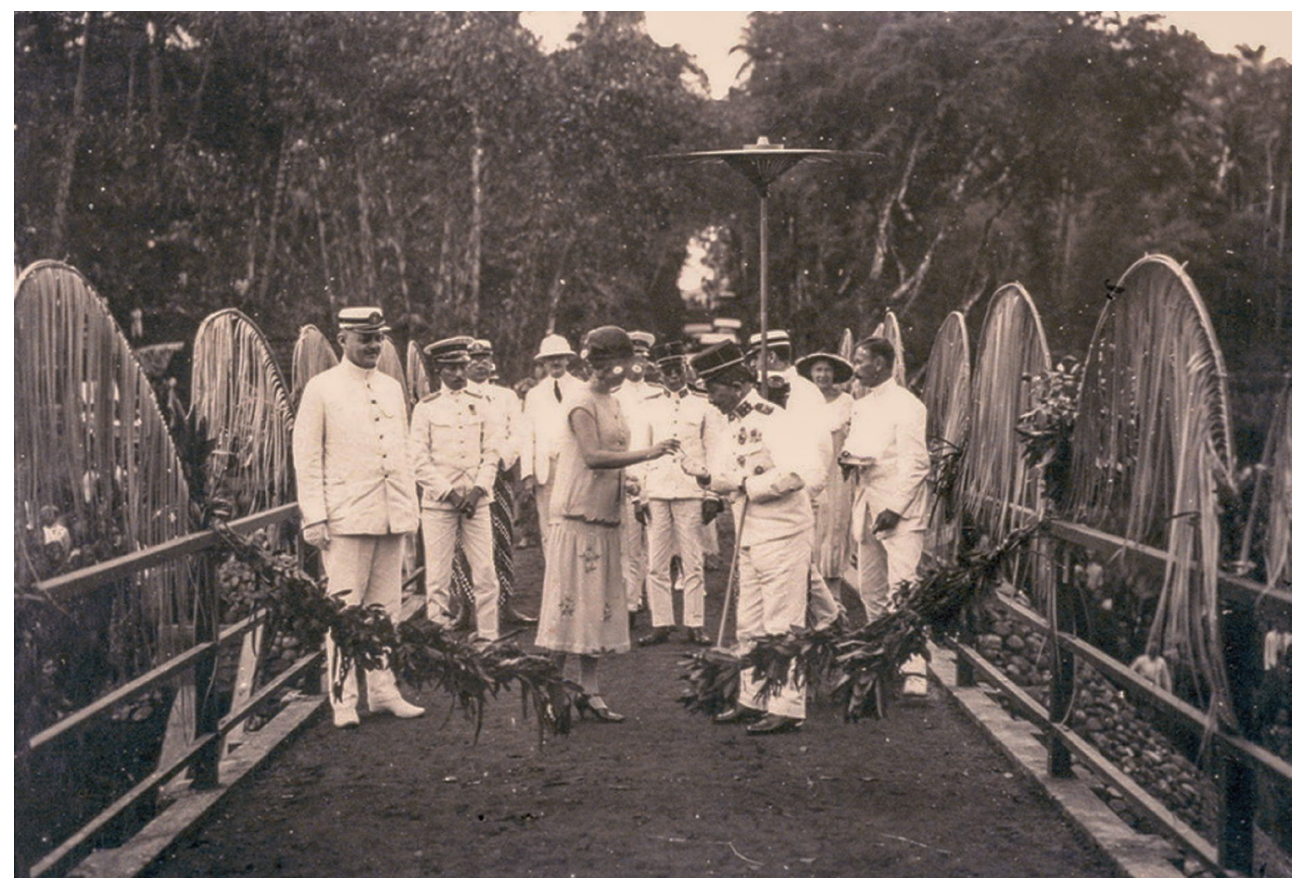

Picture 6. Resident L.F. Dingemans with Sultan Hamengku Buwana VIII when inaugurating the Serang River Bridge and Kali Klepu Bridge. (Photograph in the collection of the Widya Pustaka Pakualaman Yogyakarta, Album F).

\section{DINGEMANS AND PROPAGANDA LITERATURE}

In the early years of the twentieth century, the Dutch colonial government was facing various complex political and security issues. Many political and social movements had emerged, and despite being based on varied ideologies such as nationalism, Islam, messianic-millenarianism, nativism, and Ratu Adil, all showed anti-colonial tendencies (see Kartodirdjo 1981). Furthermore, the government had to address everyday problems such as crime (theft, robbery, murder, opium smuggling) and deviant behaviour (gambling, alcoholism, opium use, and prostitution).

The colonial government attempted a range of approaches to overcome these problems. First, it increased the number of available police and improved the capacity of existing units (Bloembergen 2002). Second, it strengthened the court system and passed numerous laws and regulations. ${ }^{5}$ Third, it spread propaganda in various forms, including pamphlets, posters, films, and books; this final approach was used by Dingemans in Yogyakarta.

In 1925, Dingemans - then the Resident of Yogyakarta - published four short stories in the Javanese language and script: Bebenduning Pangeran dateng nagari ingkang resah (God's wrath upon a restless nation), Bab Sumardi satunggaling komunis ingkang enget (Sumardi, the repentant communist),

5 Regarding the reinforcement of colonial law, particularly in the Principalities, see Van den Haspel 1985. 
Caritanipun Kacung diukum pangadilan jalaran ngobong omah (The story of Kacung, sentenced by the court for burning a house), and Caritanipun Simin diukum pangadilan amarga dadi Ratu Adil palsu (The story of Simin, punished by the court for falsely claiming to be the Just King). ${ }^{6}$ The manuscripts examined in this article exist in two versions. The first are held in the collection of KITLV Leiden, which is now part of the Leiden University Libraries. On the covers of these manuscripts (see Pictures 7 and 8 ) is typed the phrase "Voor het Zendings-Centrum v/d Gereformeerde Kerken in NEDERLAND, te BAARN" (for the Mission Center of the Reformed Churches in the NETHERLANDS, in BAARN). The name "L.F. Dingemans" is typed on the last page of each book, as well as the location and year ("Djokjakarta 1925"). In 1926 these four stories were republished, in four languages (Javanese, Sundanese, Madurese, and Dutch) by the colonial government in Yogyakarta under the title Gegevens over Djokjakarta B (Data about Djokjakarta B) (Dingemans 1926).
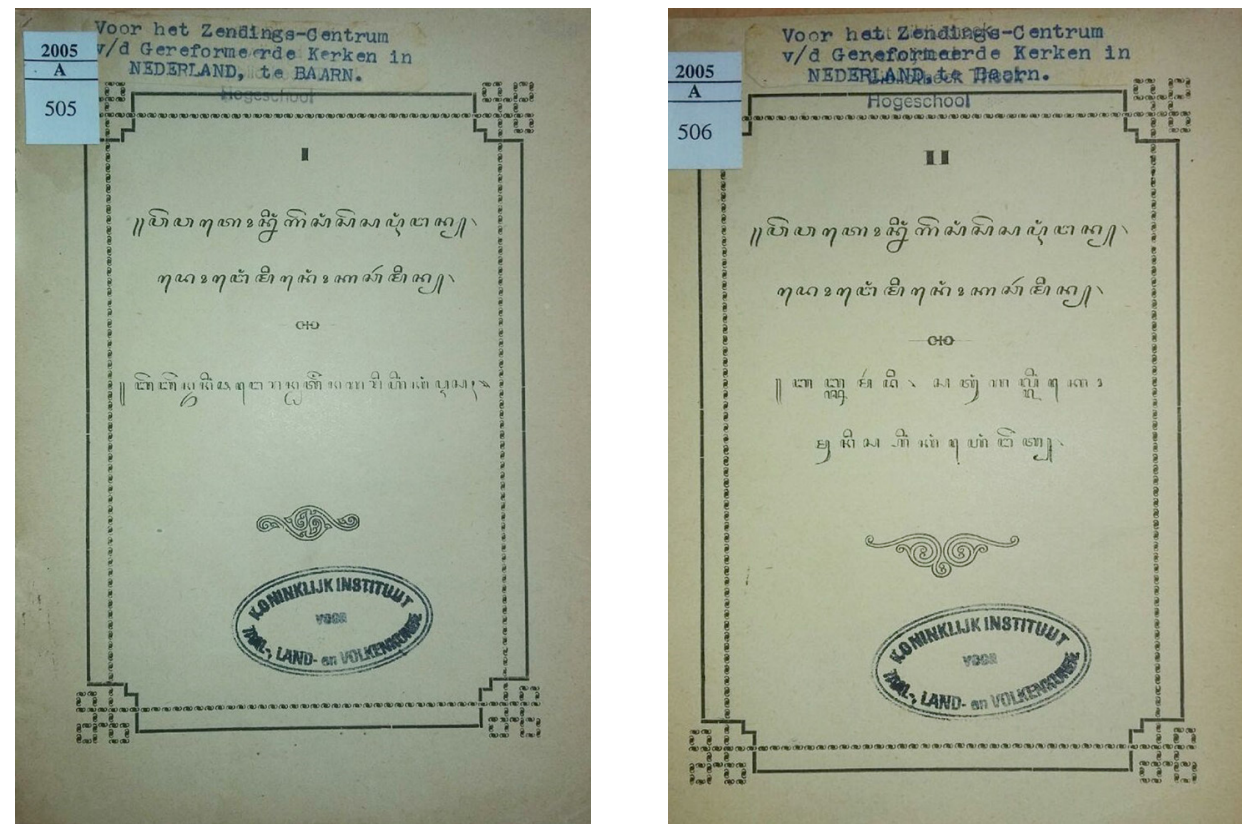

Picture 7. The covers of manuscripts I and II of the Dingeman's propaganda literature. (Photographs in the collection of Widya Pustaka Pakualaman Yogyakarta).

The first story, Bebenduning Pangeran dateng nagari ingkang resah, tells about a kiai (a teacher of Islam) who lives in a land where all people behave defiantly, and the Ma Lima (Main, Minum, Madat, Maling, dan Madon; Gambling, Drinking, Opium Use, Theft, and Whoring) are practiced openly. The kiai travels from village to village, urging local residents to abandon these habits. However, his

6 I would like to express my gratitude to Dr Abdul Wahid, who provided me with facsimile copies of these manuscripts. The second version is that included in Gegevens over Djokjakarta (B), the official periodical of the Residency of Yogyakarta, in 1926. It is essentially a transcript of the four manuscripts discussed in the text. 
efforts are in vain, and he is mocked. One day, an angel approaches the kiai and demands him to leave the land, as God would soon smite it with a great disaster. The kiai tries to negotiate with this angel, asking that God's wrath not be wrought upon the land, as it would also kill good people. The angel responded that, if the kiai could find 50 good people, God would not bring disaster to the land. Knowing that he cannot find so many good people, the kiai asks for a lower number. The angel offers 45 . The kiai and angel continue their bargaining, and the angel gives one final offer: if the kiai can find ten good people in the land, the disaster would be stopped. Before the kiai can give a counter-offer, the angel vanishes. The kiai realizes that even ten good people would be difficult to find in the land, and decides to immediately flee. As soon as he leaves, disaster strikes, and the sinful are smite by floods, earthquakes, and volcanic eruptions.

The second story is titled Bab Sumardi satunggaling komunis ingkang enget tells the story of Sumardi, a young unemployed man who is attracted to the communist movement and spreads its teachings among his neighbours. He visits his friend, a Muslim named Matahir, to urge him to join the communist movement. However, Matahir refuses, saying that communism denigrates religion as the opium of the masses and thereby denies the truth of Islam. As they debate, a devout Christian named Lukas comes and supports Matahir's rebuttal of communism. Lukas, taking Russia as an example, argues that communism can only be detrimental to a country's politics and economy. He also attempts to persuade Sumardi, using a number of arguments from a variety of perspectives - including a religious perspective. Sumardi is convinced, especially after Lukas offers him employment, and chooses to abandon communism.

The third story Caritanipun Kacung diukum pangadilan jalaran ngobong omah tells of a young man named Kacung, who is imprisoned and later exiled after razing his neighbour's house. This short story opens with the tayuban celebration, held at Tarmidi's home to celebrate the birth of his child. Kacung's misfortune begins when he attends the party, where he fights with another youth during the tayub dance. Both youths are drunk, and they attempt to approach the dancer. Tarmidi intervenes, and Kacung feels as though he has been publicly shamed. He then swears that he will burn Tarmidi's house to the ground. Several days after the party, he does so, burning down the house. In the fire, Tarmidi newborn child is killed, while Tarmidi and his wife have serious burns. After some time, the police are able to arrest Kacung, who is sentenced to twenty years in exile.

The fourth story Caritanipun Simin diukum pangadilan amarga dadi Ratu Adil palsu follows a young man named Simin, a coachman who proclaims himself Ratu Adil and takes the title Sri Moho Rojo Kusumo Di Logo Gunung Slempit Adiningrat. He marries a young woman, a former domestic servant who has become a tayub dancer, and grants her the title Siti Amini Konde Kemiri. He is able to trick the village government and claim a position as patih (deputy regent). He also convinces the village residents to pay him tribute and taxes, 
and to build him a palace. Soon the local residents become aware of Simin's deception, and report him to the police. For his deeds, Simin is arrested and imprisoned.
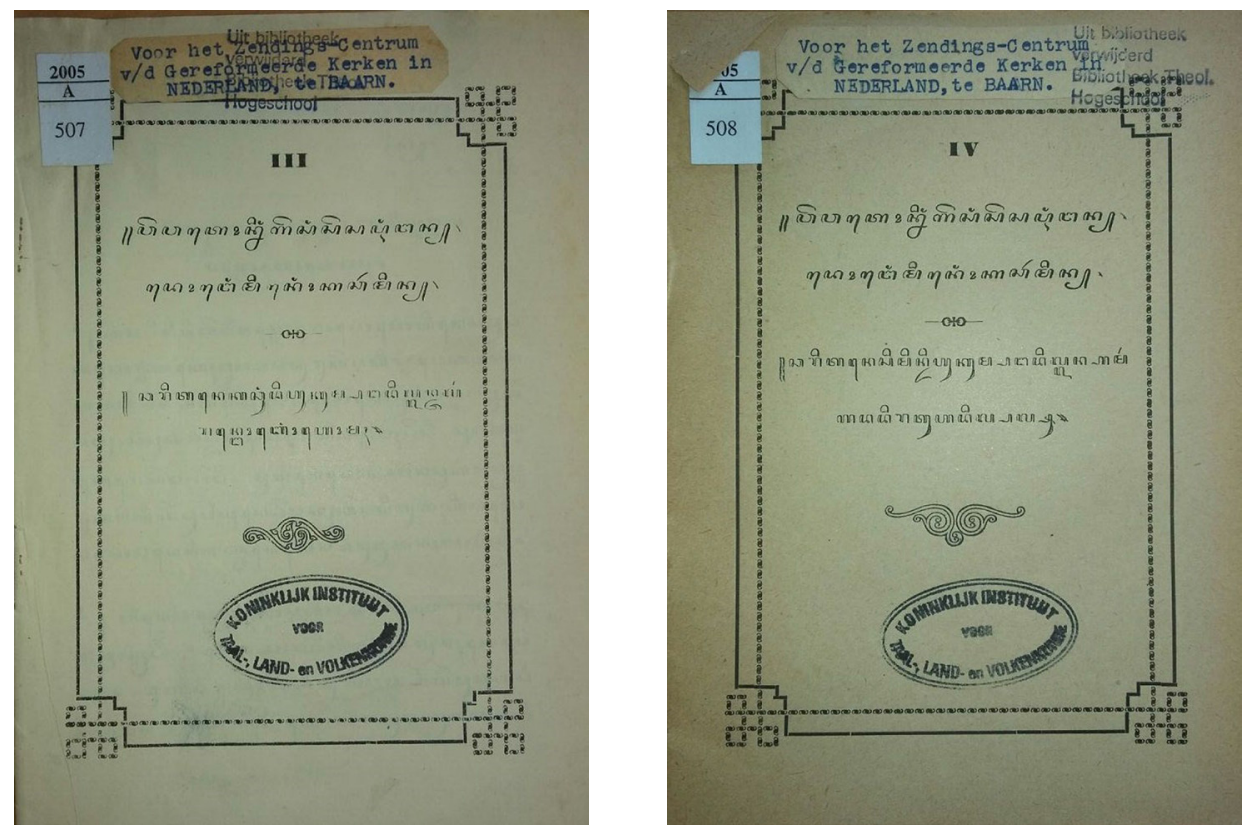

Picture 8. The covers of manuscripts III and IV of the Dingeman's propaganda literature. (Photographs in the collection of Widya Pustaka Pakualaman Yogyakarta).

\section{THE SOCIAL ROOTS OF COLONIAL PROPAGANDA}

After the Java War ended in 1830, there was no open and organized resistance to Dutch colonial power. This does not mean, however, that social opposition to colonialism ended. Social movements, with the six traits mentioned above, were endemic in Java. The basis and scope of these movements were not as broad as the Java War, but were no less concerning to the colonial government. After the loss of Dipanegara, a strong leader who was seen as Ratu Adil, local resistance leaders emerged sporadically across the island. Anyone could lead such movements, from commoners to village elites, from religious leaders to nobles. These movements were supported by a belief in Ratu Adil - also known as Satrio Piningit or Herucokro - a just leader of common heritage.

In Yogyakarta, social movements had not lost momentum following the end of the Java War. In subsequent decades, several new social movements emerged, including Gerakan Bagus Jedik (also known as Pandito Panembahan Sjeh or Takowerdi) in Surakarta (1839) and the Sarip Prawiro Sentano or Mat Sleman movement in Yogyakarta (1840). In the late nineteenth century, more violent social movements could be found in the region, particularly in the areas that grew sugarcane. Farmers burned these crops in protest of plantation policies that they perceived as detrimental to both farmers and farm laborers. This can be seen, for example, in the 1882 general strike of sugar factory 
workers in Yogyakarta, which was undertaken in response to the complex land lease processes used by European landlords and widespread extortion. Djoko Utomo (1983: 68) found that some 10,000 workers from 30 sugar factories and plantations in Yogyakarta were involved in the strike (Djoko Utomo 1983: 68).

Such a situation posed a clear threat to the rust en orde (peace and order) needed to assert colonial power, and - together with deviant social behaviour such as crime and volksondeugden - proved difficult to control. However, in the early twentieth century the colonial government's efforts to maintain rust en orde was no easier, as these movements were replaced by modern political movements and the rapidly growing seeds of nationalism. Various nationalist organizations were established, with ideologies across the political spectrum. This posed a serious threat to the colonial government, as while rightist nationalist organizations remained cooperative and conservative, leftist ones - particularly the communist party - were more radical. This became increasingly problematic as leftist elements infiltrated Islamic organizations such as Sarekat Islam, which had become the largest people's movements of the time. ${ }^{7}$ Signs of radicalism were evident in several incidents in West Java, and peaked with the PKI's decision to openly rebel against the colonial government in 1926.

In short, it may be argued that the enemies of the colonial government in the early twentieth century fell into three main categories: first, socio-religious movements, based on ideologies such as Ratu Adil, millenarianism; second, volksondeugden and crime; third, political organizations with nationalist or communist ideologies.

Recognizing the latency and endemicity of the socio-political problems it faced, the colonial government initiated several programs. It would no longer wait for incidents to occur and then respond, but take preventative measures. It took four important steps towards addressing these problems. First, it appointed a number of advisers for indigenous affairs, who were tasked primarily with providing the government with input regarding the prevention of potential threats to rust en orde. Second, it passed strict laws and legislation for dealing with the three main enemies of the colonial state. Third, it gathered the elites of society and sought their support in the monitoring of deviant activities. Fourth, it promoted rust en orde and good citizenship through a range of propaganda media, including religious sermons at churches and mosques as well as popular culture.

The publication of stories, novels, and fairy tales in both private and government media, such as the four didactic stories in Gegevens over Djokjakarta, was central to the colonial government's propaganda. It acknowledged that the level of education among the indigenous populace was increasing rapidly, as were literacy rates. At the same time, the publication and printing industry including newspapers, weekly/monthly magazines, and books - was growing quickly and finding broad popular support. As such, the use of the media, particularly literature, in propaganda was considered effective. The state

7 Regarding the leftist elements of Sarekat Islam, see Ensering 1983. 
publisher Balai Poestaka was one of the colonial government's pioneers in spreading literary propaganda.

To ensure it reached the broadest audiences, this propaganda literature was not only published in Dutch, but also in widely spoken indigenous languages such as Malay and Javanese as well as local languages such as Sundanese and Madurese.

Resident Dingemans, in his introduction to Gegevens over Djokjakarta, wrote that the 1926 publication was a continuation of his earlier publications in 1925. This edition had been published because of the previous edition's broad public acclaim and demand for further stories. As such, Resident Dingemans felt it necessary to include the four didactic stories. Their inclusion was strategic; as the book would be widely read, the propaganda contained within his stories would have a similarly broad reach. It is not surprising that Surakarta and Yogyakarta received special attention, given the broad support that social movements had received in these cities.

\section{THE INSTITUTIONALIZATION OF LITERATURE AS COLONIAL PROPAGANDA}

The involvement of colonial officials such as Dingemans in the production of literary and non-literary written material meant for indigenous audiences in the Netherlands East Indies had deep roots, reaching back to the end of the Java War. They began providing reading materials to colonial employees who would be stationed in the Netherlands East Indies, who were required to understand the local language and culture. Generally, the colonial employees involved in literary production worked for the government as translators and advisers. An interesting study of this phenomenon was conducted by C. Fasseur and the Japanese scholar Kenji Tsuchiya. Fasseur argues that, to gain a command of the Javanese language and literature, these colonial employees (popularly known as indologen) would use Javanese scribes and writers as born van nutritie (sources of nutrition) during their studies (Fasseur 1992). Tsuchiya (1998) writes, they became "Javanists" who went from transcribing and translating classical works of Javanese literature to adapting and creating new literary works that contained and conveyed modern knowledge. The literature that they produced received increasingly broad readership as advances were made in printing technology. Over time, the palace scribes were marginalized and became less effective (Tsuchiya 1998).

In the first twentieth century, the colonial government established the Kantoor voor het Volkslectuur (Office for People's Reading Material), which became the official state publisher Balai Poestaka. This institution sought to develop and promote literary materials that it considered "of appropriate quality" for the common people. One writer who has examined the involvement of this colonial institution in literary production during the colonial era is Doris Jedamsky. In her post-colonial approach study, she likened Balai Poestaka to a "wolf among sheep". According to Jedamsky (1992: 23-46), Balai Poestaka was a multi-functional institution, a colonial agency of socialization. 
It played an important role in conveying western concepts of cognition, i.e. designing and setting of values, models of behavior, and new sets of social roles, all of which correspond to the decisive change in colonial society around the turn of the century (Jedamsky 1992: 23).

Despite Balai Poestaka's massive list of publications and high level of productivity through the early twentieth century, the colonial government felt it was insufficient. Other government agencies and institutions thus created their own periodicals, which were used to promote their programs and socialize their plans and strategies. In such periodicals, works of propaganda literature were included. This includes Gegevens over Djokjakarta, published by Resident Dingemans in Magelang, who felt it necessary to include his stories so that they would reach an appropriate audience. The publication was compulsory reading for all colonial officials, as well as the nobility in the Yogyakarta Palace.

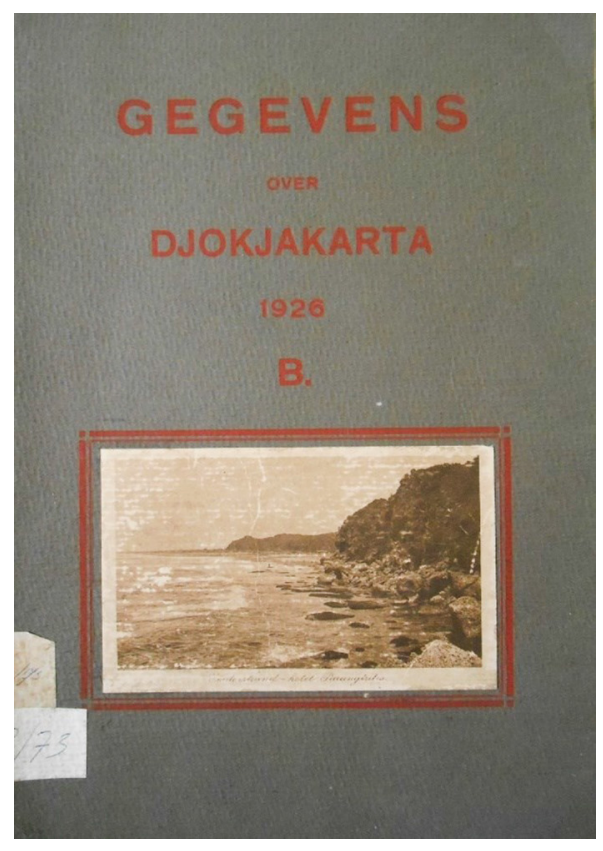

Picture 9. The cover of the annual publication of the Dutch Resident of Yogyakarta where the Dingeman's propaganda literature were published in Dutch. (Collection of Widya Pustaka Pakualaman Yogyakarta, 175).

Gegevens over Djokjakarta, published in two volumes (A and B), was the official periodical of the Yogyakarta government. It contained articles on a range of themes, including governance, law, tourism, government plans/ programs, society, politics, and economics, as well as some advertisements. This periodical also included various photographs of the natural beauty of Yogyakarta, of the Sultan, and of the colonial government officials in the city. This periodical was only published under Dingemans' leadership; 
Yogyakarta's previous and subsequent residents did not publish such works. As such, it may be concluded that Gegevens over Djokjakarta was designed by Resident Dingemans to promote the interests of his government during his time as resident.

Based on the articles included within Gegevens over Djokjakarta, it may be concluded that the book served to promote tourism, promote government programs, promote new laws and legislation, and (of course) promote specific social and political interests while stemming the rise of socio-political movements (see Picture 9 for the cover of the publication).

\section{COLONIAL LITERATURE FROM A POSTCOLONIAL PERSPECTIVE}

The postcolonial analysis of this study is based on the concepts presented by Ania Loomba in her "Colonialism and post-colonialism" (Loomba 2016: 104-109). According to Loomba, when discussing literature and colonialism, literary texts must be understood as compilations of linguistic units and signs that provide fertile ground for the interactions of ideologies. Literary works are propagated by colonial governments as part of their colonial institutions, including their education systems. Through such institutions, colonial governments play an important role in granting themselves cultural authority, both at home and in the colony. Literary works also reflect the dominant ideologies and encode the tensions, complexities, and nuances of colonial culture. "New worlds" (those are colonies) is understood by colonial governments through the filters of their own ideologies and perspectives. Colonial governments' interpretation of colonized peoples is also driven by their desire to trade with, exert control over, and colonize new lands. Loomba emphasizes that language and literature are involved in creating binary opposition between the European "self" and non-European "other". This, Edward Said argues, is part of how colonial governments create their power (Loomba 2016: 104-109).

In the first story, Bebenduning Pangeran dateng nagari ingkang resah (God's wrath upon a restless nation), the colonial perspective (reflecting, in this case, Dingemans' perspective) presents a Muslim religious leader (in this story, the kiai) idealistically as a doctor with the ability to treat social diseases, or volksondeugden. However, the religious leader does not offer an effective solution; more explicitly, the kiai cannot optimally fulfil his role as healer of social diseases. It appears that, through this story, Dingemans argued that the Muslim-majority lands such as Yogyakarta, despite having very vocal religious leaders, lack the capacity to overcome volksondeugden, and may even willing to allow people to be smite by God rather than fulfil their obligations. This is a veiled insult at the Yogyakarta-based Muhammadiyah movement, which was established in 1912 and was growing rapidly by the time the story was written.

This differs significantly with the depiction of Lukas, a Christian, who is able to persuade the communist Sumardi to abandon his ideology in the second story, Bab Sumardi satunggaling komunis ingkang enget (Sumardi, the repentant communist). Lukas convinces Sumardi that communism fails to 
reflect the realities of societies that have embraced it, using rational and databased arguments that reference communist Russia. Lukas, the Christian, is not only able to provide a persuasive argument, but also solve Sumardi's problem by providing him with employment. The depictions of these two religious figures offer a stark contrast; where the Muslim is shown as being only able to solve problems through sermons and prayer, the Christian is presented as offering concrete solutions and counter the draw of communism. Such subjectivity is also evident in Dingemans' real-life promotion of Christian interests over Muslim ones, such as in the case of the Christmas/Garebeg Maulud celebrations.

The third story, Caritanipun Kacung diukum pangadilan jalaran ngobong omah (The story of Kacung, sentenced by the court for burning a house), presents another example of an acute social disease that Dingemans perceived as afflicting the Javanese of all walks of life. The Javanese, in this story, are presented as prioritizing their parties and their guests over the warnings of colonial officials. Tarmidi's decision to host a party and a tayub dance ultimately leads to the death of his newborn child. Meanwhile, Kacung's drunkenness leads to him being exiled. In this story, the Javanese are depicted as enjoying parties, as ignoring the advice of state officials, and as cultivating grievances.

Where the first and second stories present Christianity as superior to Islam in its ability to overcome social diseases, Caritanipun Simin diukum pangadilan amarga dadi Ratu Adil palsu (The story of Simin, punished by the court for falsely claiming to be the Just King) presents a colonial perspective of Ratu Adil movements, painting them as nasty, cunning, and deceitful. Simin, a commoner, portrays himself as a king, reflecting elements of the wayang (shadow puppet) story "Petruk dadi Ratu" that had been popular since the nineteenth century. Dingemans presents Simin as a "surprise king", one who abuses his position and gave himself a pompous and even bawdy title. Simin also takes a "fallen woman", a former domestic servant who had become a dancer (read: prostitute), as his wife, giving her a similarly bawdy title. This fourth story may be understood as colonial mockery of commoners' subversive activities, portraying them as lacking political savvy and as easily being caught by the colonial police.

\section{CONCLUSION}

As didactic works of literature, the four short stories discussed in this article provide a simple lesson: improper behaviour will result only in disaster for oneself. Perpetrators of such behaviour will face severe punishment, be it imprisonment, exile, or even God's wrath. In Ania Loomba's postcolonial theory, these four works of colonial propaganda may be perceived as resulting from the ideological interactions between Dingemans (as a colonial official) and the colonized peoples of Yogyakarta. These four stories were integral to the city's colonial institutions and European missionary community, in which Dingemans was personally involved. These stories reflect the tensions, complexities, and nuances of colonial culture, as well as how the colonial government viewed 
indigenous socio-political behaviour through its ideological filter. Language is an important part of the colonial hegemony. As such, Dingemans' stories are interesting, as they were published in Javanese and used to communicate colonial ideas and perspectives. Dingemans' language enabled him to create binary opposition between Europeans and non-Europeans.

Literacy was an important element of colonialism, and an essential tool for early twentieth colonial activities. Colonial literature emphasized three elements. First, it underscored Europeans' hegemony and superiority, presenting them as more civilized and thus more capable of monitoring sociopolitical behaviour and creating good colonial citizenship. Second, it canonized codes of good conduct (in a Western perspective) and set sanctions for violators. Third, it presented native narrativism, using local languages as a means of communication while clearly distinguishing between the languages of those in power (colonizer) and colonial subjects (colonized). Colonial propaganda literature was replete with mockery of indigenous behaviours that were seen as emphasizing religious performativity over the ability to provide solutions and promote progress.

\section{BIBLIOGRAPHY}

KITLV MANUSCRIPTS

Bebenduning Pangeran dateng nagari ingkang resah (God's wrath upon a restless nation),

Bab Sumardi satunggaling komunis ingkang enget (Sumardi, the repentant communist),

Caritanipun Kacung diukum pangadilan jalaran ngobong omah (The story of Kacung, sentenced by the court for burning a house),

Caritanipun Simin diukum pangadilan amarga dadi Ratu Adil palsu (The story of Simin, punished by the court for falsely claiming to be the Just King).

\section{PHOTOGRAPHS}

Collection of the Tropenmuseum

TM 60041526 (Picture 1)

TM 60041535 (Picture 3)

TM 60041536 (Picture 2)

TM 60041546 (Picture 4)

Collection of Widya Pustaka Pakualaman Yogyakarta, Album F (Pictures 5-9)

\section{BOOKS AND ARTICLES}

Alexander, Jennifer and Paul Alexander. 1982. "Shared poverty as ideology; Agrarian relationships in colonial Java", Man Vol. 17 No. 4 (December): 597-619.

Alfian. 1989. Muhammadiyah; The political behaviour of a Muslim modernist organization under the Dutch colonialism. Yogyakarta: Gadjah Mada University Press. 
Bloembergen, Marieke. 2002. Polisi zaman Hindia Belanda. Jakarta: Penerbit Kompas.

Carey, Peter. 2011. Kuasa ramalan; Diponegoro dan akhir tatanan lama di Jawa, 1785-1855. Jakarta: Gramedia.

Delair Noer. 1973. The modernist muslim movement in Indonesia, 1900-1942. Oxford: Oxford University Press.

Dingemans, L.F. 1926. Gegevens over Djokjakarta B. Magelang: Maresh.

Djoko Utomo. 1983. “Pemogokan buruh tani di abad ke-19; Kasus Yogyakarta, Prisma, No. 8 (August): 68-78.

Ensering, Else. 1983. Afdeling B van de Sarekat Islam; Een opstandige islamitische beweging. Amsterdam: Vrije Universiteit, subfakulteit NWS/CA, Kontaktgroep Tropisch Azië.

Fasseur, C. 1992. "The France scare; Taco Roorda and the origins of Javanese studies in the Netherlands", in: V.J.H. Houben and H.H.J. Maier (eds), Looking in odd mirrors; Java and the Java Sea, pp. 241-257. Leiden: Vakgroep Talen en Culturen van Zuidoost Azië en Oceanië.

Haspel, C.Ch. van den. 1985. Overwicht in overleg; Hervormingen van justitie, grondgebruik, en bestuur in de vorstenlanden op Java, 1880-1930. Dordrecht: Foris. [Verhandelingen van het Koninklijk Instituut voor Taal-, Land- en Volkenkunde 111.]

Jedamsky, Doris. 1992. "Balai Pustaka; A colonial wolf in sheep's clothing", Archipel; Études interdisciplinaires sur le monde insulindien Vol. 44: 23-46.

Loomba, Ania. 2016. Kolonialisme/Pascakolonialisme. Yogyakarta: Narasi and Pustaka Promethea.

Nakamura, Mitsuo. 1983. Bulan sabit muncul dari balik pohon beringin; Studi tentang Pergerakan Muhammadiyah di Kotagede Yogyakarta. Yogyakarta: Gadjah Mada University Press.

Nakamura, Mitsuo. 2012. The crescent arises over the Bayan Tree; A study of the Muhammadiyah Movement in Central Javanese town, c. 1910s-2010. Singapore: Institute of Southeast Asian Studies.

Niel, Robert van. 1960. The emergence of the modern Indonesian elite. Bandung: W. van Hoeve.

Sartono Kartodirdjo. 1981. Laporan-Laporan gerakan protes di Jawa pada abad XX. Jakarta: ANRI.

Shiraisi, Takashi. 1990. An age of motion; Popular radicalism in Java, 1912-1926. Ithaca, NY: Cornell University Press.

Steenbrink, Karl. Dutch colonialism and Indonesian Islam; Contacts and conflicts, 1596-1950. Amsterdam: Rodopi.

Steenbrink, Karel. 2007. Catholics in Indonesia, 1808-1942; A modest recovery 1808-1903. Leiden: KITLV Press.

Sutherland, Heather. 1976. The making of a bureaucratic elite; The colonial transformation of the Javanese priyayi. Singapore: Heinemann. [Asian Studies Association of Australia, Southeast Asia Publications Series 2.]

Tsuchiya, Kenji. 1998. "Javanology and the age of Ranggawarsita; An introduction to nineteenth century Javanese culture", in: Reading Southeast Asia, pp. 75-108. Ithaca, NY: Southeast Asia Program, Cornell University. 